\title{
Strefa Schengen w dobie kryzysu imigracyjnego
}

\begin{abstract}
Streszczenie: Przedmiotem rozważań niniejszego artykułu są zagadnienia związane z funkcjonowaniem strefy Schengen w czasie kryzysu imigracyjnego, jaki dotknął Europę w 2015 roku i w pierwszej połowie 2016 roku. W rozważaniach odniesiono się do genezy, istoty i znaczenia obszaru Schengen w procesie integrowania się kontynentu europejskiego. Przeanalizowano zjawisko niekontrolowanego wzrostu imigrantów przybywających do Europy pod względem ilościowym, uwzględniając jego skutki i znaczenie dla istnienia obszaru Schengen. Zwrócono uwagę na decyzje państw strefy Schengen, które w obawie przed narastającą falą imigrantów wprowadzały tymczasowe kontrole na granicach. Uwzględniono inicjatywy podejmowane przez państwa europejskie w celu rozwiązana kryzysu imigracyjnego, ale i wyeksponowano brak solidarności w tych działaniach. W konkluzji autorka stwierdza, iż w najbliższym czasie strefa Schengen się nie rozpadnie, ale żeby przetrwała musi się zaadoptować do nowych okoliczności za pomocą reform i wzmocnić kontrole na granicach zewnętrznych.
\end{abstract}

Słowa kluczowe: strefa Schengen, kryzys imigracyjny, imigranci, Europa, Unia Europejska

$\mathbf{N}$ iespotykana fala imigrantów jaka dotarła do Europy w 2015 roku stała się poważnym wyzwaniem dla funkcjonowania strefy Schengen. Motywem, dla którego tak wiele osób zdecydowało się opuścić Syrię, Libię, Afganistan, Irak, była amerykańska i europejska polityka interwencyjna, która pozostawiła te państwa w stanie destabilizacji i gospodarczej stagnacji. Bezprecedensowy napływ imigrantów w dużej mierze determinowany był i jest położeniem geograficznym Europy, znacznie trudniejszym niż innych światowych potęg takich jak Chiny czy Stany Zjednoczone. Relatywnie w nieznacznej odległości od Starego Kontynentu położony jest Bliski Wschód, Północna Afryka, Afganistan i Pakistan, gdzie toczą się najważniejsze konflikty zbrojne na świecie i w konsekwencji znajdują się największe skupiska migrantów.

Rosnąca ilość imigrantów docierających do Europy wywołała podziały i napięcia między państwami europejskimi, czego przejawem był między innymi wzrost poparcia dla partii eurosceptycznych i nacjonalistycznych oraz postaw islamofobicznych. Włochy, Grecja, Hiszpania czy Niemcy, do których przybywa fala niechcianych imigrantów domagają się od swoich sojuszników solidarnego udziału w ich przyjmowaniu. Pojawiła się propozycja stworzenia mechanizmu automatycznego i przymusowego rozdzielania cudzoziemców pomiędzy państwa członkowskie Unii Europejskiej. Jednak nie wszystkie państwa to akceptują. Debata o imigrantach jeszcze przez długi czas pozostanie tematem numer jeden w całej Europie. Pewne jest jedno, że konsekwencje niekontrolowanej emigracji do Europy mogą być katastrofalne dla strefy Schengen. Z drugiej jednak strony kryzys masowego napływu imigrantów, jaki dotknął państwa europejskie, może przyczynić się do wyjątkowego postępu integracji UE poprzez wzmocnienie współpracy w sferze ochrony granic zewnętrznych.

Przedmiotem niniejszych rozważań jest zagadnienie dotyczące strefy Schengen w dobie kryzysu imigracyjnego. Przy czym strefa Schengen to obszar, w którym obo- 
wiązuje swoboda przemieszczania się i nie są przeprowadzane kontrole na granicach wewnętrznych państw, przy zachowaniu ścisłych i ujednoliconych kontroli na granicach zewnętrznych.

Z kolei kryzys imigracyjny, którego początek przypadł na 2015 rok, to masowy niekontrolowany wzrost imigrantów przybywających do Europy. W 2015 roku, w państwach Unii złożono rekordową liczbę 1,2 miliona wniosków o azyl. Według danych UNHCR, wśród imigrantów, którzy dotarli do Europy w 2015 roku, znajdowali się przede wszystkim Syryjczycy (49\%), Afgańczycy (21\%) i Irakijczycy (8\%). Wnioski o azyl złożone zostały przede wszystkim w Niemczech (476 tys. wniosków), w Szwecji, w Austrii i na Węgrzech. Tylko podczas dwóch pierwszych miesięcy 2016 roku do wybrzeży Grecji przybiły kolejne 123 tys. osób. Dla porównania, w tym samym okresie roku 2015 było ich zaledwie 4,6 tys. (Obecny kryzys, 2015). Blokady i ograniczenia wprowadzane na granicach przez poszczególne państwa należące do strefy Schengen, prowadziły do gromadzenia się dużej liczby migrantów na terenach przygranicznych. Dodatkowo wprowadzanie pod koniec 2015 r., przez kolejne państwa, chaotycznych i zmieniających się zasad selekcji imigrantów na podstawie oceny szans otrzymania przez nich azylu doprowadziło do kryzysów dyplomatycznych i humanitarnych.

Celem niniejszego tekstu jest udzielanie odpowiedzi na następujące pytania: Jak kształtowała się strefa Schengen i jak kryzys imigracyjny wpłynął na jej funkcjonowanie i czy może on doprowadzić do rozpadu strefy Schengen?

Dobór metod badawczych w niniejszym tekście podporządkowano obszarowi badań i dążeniu do znalezienia wyczerpujących odpowiedzi na postawione pytania. W rozważaniach zastosowano historyczną metodę genetyczną, która okazała się niezwykle pomocna przy eksploracji genezy zagadnienia powstania strefy Schengen i podejmowanych działań w walce z kryzysem imigracyjnym. Oprócz tego niezmiernie istotną okazała się metoda systemowa, decyzyjna i porównawcza.

\section{Geneza i funkcjonowanie strefy Schengen}

Genezy strefy Schengen należy szukać w 1974 roku, kiedy to rozpoczęto zmagania związane z opracowaniem planu niezbędnego do utworzenia unii paszportowej, wprowadzającej jednolite dokumenty dla obywateli państw członkowskich Wspólnot Europejskich (WE) oraz zniesienia granic zewnętrznych tych państw. Poszukiwanie wspólnych rozwiązań w tej kwestii trwało dziesięć lat. Ostatecznie w maju 1984 r., przed szczytem Rady Europejskiej, ministrowie transportu państw członkowskich WE na posiedzeniu Rady Ministrów zobowiązali się do liberalizacji i harmonizacji zasad przekraczania granic. Decyzje te poprzedziły konsultacje niemiecko-francuskie w Fontainebleau w dniach 25-26 czerwca $1984 \mathrm{r}$. Zakończyły się one porozumieniem w sprawie stopniowego znoszenia kontroli na wspólnej granicy. Dzięki tym ustaleniom podczas szczytu powołano tzw. komitet Adonnino, przed którym postawiono zadanie opracowania zasad jak najszybszego zniesienia formalności policyjnych i celnych przy przekraczaniu granic wewnętrznych na obszarze WE. Zalecenia powyższego komitetu nie zostały przyjęte przez wszystkie państwa (Gruszczak, 2012, s. 29). Wówczas to Francja i Niemcy zdecydowały się na podjęcie samodzielnej próby osiagnięcia postawionych celów. W czerwcu 
1984 r. prezydent Francji Francois Mitterand oraz kanclerz Republiki Federalnej Niemiec Helmut Kohl podpisali w Saarbrücken porozumienie w sprawie stopniowego znoszenia kontroli na wspólnych granicach. Wkrótce do układu tego postanowiły dołączyć państwa Beneluksu. W ten sposób 14 czerwca 1985 r. w miejscowości Schengen w Luksemburgu doszło do podpisania układu między rządami państw Unii Gospodarczej Beneluksu, Republiki Federalnej Niemiec oraz Republiki Francuskiej w sprawie znoszenia kontroli na wspólnych granicach. Umowa ta zawarta była poza strukturami Europejskiej Wspólnoty Gospodarczej i nie była częścią prawa wspólnotowego. Układ z Schengen I składa się z 33 artykułów. Zawarte są w nich konkretne środki i rozwiązania, dzięki którym w przeciagu kilku lat, pięć państw osiagnąć miało całkowite zniesienie kontroli na wspólnych granicach. Oznaczało to utworzenie unii paszportowej. Niejako więc w integrującym się obszarze Wspólnot Europejskich (WE) miał istnieć jeszcze bardziej zintegrowany i połączony ze sobą obszar. Środki, jakie są zawarte w Układzie, dzielą się na środki krótkoterminowe zapisane w Tytule I Układu oraz na środki długoterminowe zapisane w Tytule II Układu. Art. 30 przewidywał, że środki krótkoterminowe wejdą w życie od dnia 1 stycznia 1986 r., a środki długoterminowe od dnia 1 stycznia $1990 \mathrm{r}$. W zawartym porozumieniu do środków krótkoterminowych zaliczono: wprowadzenie wspólnej odprawy granicznej, zastąpienie kontroli szczegółowej zwykłą kontrolą wzrokową przejeżdżających pojazdów, wprowadzenie możliwości przekraczania granicy dla mieszkańców terenów przygranicznych w dowolnym czasie, a także poza punktami kontroli granicznej, wprowadzenie ułatwień poprzez zniesienie szczegółowych kontroli dla kierowców trudniących się zarobkowym przewozem osób, a także transgranicznym transportem towarów. Natomiast środki długoterminowe zawarte w Układzie z Schengen obejmowały: całkowite zniesienie kontroli na wspólnych granicach wewnętrznych poprzez przesunięcie ich na granice zewnętrzne, harmonizację polityk wizowych i zasad wjazdu obywateli państw trzecich na terytorium państw strefy Schengen, wypracowanie środków, w celu zapobiegania nielegalnej imigracji z państw niebędących członkami Wspólnot, zwiększenie poziomu bezpieczeństwa wewnętrznego państw, które zawarły ten Układ, harmonizację przepisów dotyczących kontroli granicznych, a także dotyczących broni i materiałów wybuchowych, środków odurzających i meldowania podróżnych w hotelach. Dla realizacji tych celów postanowiono współpracować zarówno na poziomie państw, które zawarły Układ, jak i na poziomie Wspólnot Europejskich (Dereń, 2014; Czapliński, 1992, s. 97-98).

Istotnym uzupełnieniem i rozwinięciem tej umowy była podpisana w dniu 19 czerwca 1990 r. Konwencja Wykonawcza do Układu z Schengen tzw. Układ Schengen II, który określał warunki likwidacji kontroli na granicach wewnętrznych oraz zakres środków rekompensujących ewentualne zagrożenia dla bezpieczeństwa wewnętrznego, w tym działania dotyczące ustanowienia wspólnych zasad kontroli granic zewnętrznych. Państwa podpisujące Konwencję Wykonawczą zdecydowały się na całkowite zniesienie kontroli na ich wspólnych granicach. Jednak zastrzegły sobie prawo, zgodnie z art. 2 ust. 2 Konwencji Wykonawczej, do ich przywrócenia w razie ewentualnego zagrożenia dla interesów państwa bądź jego ludności (Konwencja Wykonawcza do Układu $z$ Schengen). Zgodnie z postanowieniami Konwencji w strefie Schengen kontrole na granicach wewnętrznych mogły być przywracane na następujących zasadach: powodem ich przywrócenia jest sytuacja wyjątkowa (zagrożenie dla porządku publicznego lub 
bezpieczeństwa); kontrole przywracane na okres ograniczony; przywrócenie kontroli obejmuje czynności kontrolne właściwe dla zaistniałej sytuacji; przywrócenie kontroli zasadniczo wprowadzane jest po konsultacjach z pozostałymi państwami członkowskimi strefy; przywrócenie kontroli nie wymaga zgody pozostałych państw strefy Schengen. Ostatecznie kontrole na wspólnych granicach zniesiono dopiero 10 lat później, kiedy to 26 marca 1995 roku weszła w życie Konwencja Wykonawcza do Układu z Schengen (Trojanowska-Strzęboszowa, 2014a, s. 48-49).

Obecnie $^{1}$ obszar Schengen tworzy 26 państw. Wśród nich 22 należą do Unii Europejskiej - są to: Belgia, Holandia, Luksemburg, Francja, Republika Federalna Niemiec (które to państwa podpisały porozumienie 14 czerwca 1985 r.), Włochy (które przystapiły do układu 27 listopada 1990 r.), Hiszpania i Portugalia (dołączyły 25 czerwca 1991 r.), Grecja (podpisała porozumienie w 6 listopada 1992 r.), Austria (od 28 kwietnia 1995 r.), Dania (z klauzulą opt-out), Finlandia i Szwecja (od 19 grudnia 1996 r). Polska, Republika Czeska, Estonia, Łotwa, Litwa, Węgry, Malta, Słowenia i Słowacja przystapiły 21 grudnia $2007 \mathrm{r}$. Członkami strefy Schengen są również cztery państwa niebędące członkami Unii Europejskiej, które przystapiły do obszaru Schengen kolejno: Norwegia i Islandia w 2001 r., Szwajcaria podpisała pierwsze stosowne porozumienia w 2004 roku, ale dopiero w 2009 r. stała się pełnoprawnym członkiem strefy Schengen, Liechtenstein w 2011 r. W Wielkiej Brytanii i Irlandii, z uwagi na specyfikę geograficzną, nie zniesiono kontroli granicznych. Jednak państwa te mogą stosować niektóre postanowienia dotyczące współpracy policyjnej i sądowej w sprawach kryminalnych (Dereń, 2014; Pyl, 2008, s. 103-104).

Włączenie dorobku Schengen ${ }^{2}$ w ramy prawne Unii Europejskiej nastapiło w wyniku podpisania Traktu amsterdamskiego 2 października $1997 \mathrm{r}$. Traktat wszedł w życie 1 maja 1999 r. Od tej pory decyzje dotyczące obszaru Schengen podejmowane były na poziomie wspólnotowym - jako jedna z ważniejszych polityk Unii Europejskiej. Jednocześnie państwa członkowskie zgodziły się na pewne wyjątki, które - zauważyć należy - skomplikowały strukturę UE, wprowadzając tzw. zmienną geometrię (Gruszczak, 2012, s. 29, Lesiewicz, 2015, s. 125-126).

Główna część acquis Schengen - związana z procedurami przekraczania granic zewnętrznych i kontroli osób na tych granicach wraz z politykami wizową i azylową - została wówczas umieszczona w nowym Tytule IV Traktatu ustanawiającego Wspólnotę Europejska (Wersja skonsolidowana Traktatu...). Pozostała część schengeńskiego prawodawstwa, obejmująca instrumenty dotyczące bezpieczeństwa, została wprowadzona do Tytułu VI Traktatu o Unii Europejskiej (Traktat o Unii...).

Dorobek prawny Schengen, przyjęty przez Unię Europejską stał się podstawą utworzenia Przestrzeni Wolności, Bezpieczeństwa i Sprawiedliwości. Po rewizji traktatowej,

${ }^{1}$ Stan na październik 2016 roku.

2 Za dorobek Schengen uznano: Układ z Schengen, Konwencję Wykonawczą do Układu z Schengen, porozumienia, protokoły i układy o akcesji kolejnych państw, decyzje i deklaracje Komitetu Wykonawczego, decyzje Grupy Centralnej wydane na podstawie zgody Komitetu Wykonawczego, trzy załączniki - do Wspólnej Instrukcji Wizowej, Wspólnego Podręcznika Kontroli Granicznej i podręcznika SIRENE, trzy dokumenty dotyczące stosowania przesyłki kontrolowanej do zwalczania handlu narkotykami, nielegalnego stosowania narkotyków, a także wzmocnienia kontroli na granicach zewnętrznych. 
przeprowadzonej na mocy Traktatu z Lizbony, kwestie związane z Schengen znajdują się w Części III Traktatu o funkcjonowaniu Unii Europejskiej, dotyczącej polityki i działań wewnętrznych Unii Europejskiej (Wersja skonsolidowana Traktatu o funkcjonowaniu...). Od 1 maja 1999 r. współpraca w ramach Schengen zaczęła być prowadzona w ramach instytucjonalno-prawnych UE. W odniesieniu do granic wewnętrznych propozycja Komisji Europejskiej z 2004 r. utrzymywała zasadniczo treść art. 2 Konwencji Wykonawczej do Układu z Schengen oraz decyzji Komitetu Wykonawczego, precyzującego zasady przywracania kontroli na granicach.

Odnotować także należy, iż w dniu 15 marca 2006 r. Rada przyjęła Kodeks Graniczny Schengen. W art. 23-31 Kodeksu zawarto przepisy odnoszące się do tymczasowego przywracania kontroli granicznych na granicach wewnętrznych. Zgodnie z głównym postanowieniem zawartym w art. 23 Kodeksu Granicznego Schengen kontrole graniczne na granicach wewnętrznych mogły być tymczasowo przywrócone na bardzo konkretnych zasadach: w przypadku poważnego zagrożenia porządku publicznego lub bezpieczeństwa wewnętrznego państwo członkowskie może wyjątkowo przywrócić kontrolę graniczną na swoich granicach wewnętrznych na czas ograniczony nie dłuższy niż 30 dni, zgodnie z procedurą określoną w art. 24 lub, w nagłych przypadkach, zgodnie $\mathrm{z}$ procedurą określoną $\mathrm{w}$ art. 25 . Zakres i czas trwania tymczasowego przywrócenia kontroli granicznej na granicach wewnętrznych nie przekraczają tego, co jest ściśle niezbędne dla reakcji na poważne zagrożenie. Jeżeli poważne zagrożenie porządku publicznego lub bezpieczeństwa wewnętrznego trwa dłużej niż określono w ust. 1, państwo członkowskie może przedłużyć kontrolę graniczną z powodów, o których mowa w ust. 1, uwzględniając wszelkie nowe okoliczności, przez odnawialne okresy do $30 \mathrm{dni}$, zgodnie z procedurą określoną w art. 26 (Kodeks Graniczny Schengen, 2006; Trojanowska-Strzęboszowa, 2014a, s. 50-51).

Mechanizmem konsolidującym państwa tworzące schengeński obszar wspólnego podróżowania jest System Informacyjny Schengen (SIS). Jest to scentralizowane i zautomatyzowane narzędzie kontrolujące prawidłowe funkcjonowanie tej strefy. Akumuluje i przesyła do użytkowników w państwach członkowskich dane dotyczące bezpieczeństwa tego obszaru, zarówno w trybie zapobiegawczym (np. wykaz osób stanowiących zagrożenie dla bezpieczeństwa wewnętrznego i ładu publicznego), jak i następczym (np. osoby poszukiwane w celu ekstradycji). SIS to szybkie i niezbędne narzędzie współpracy sądowo-karnej, umożliwiające np. automatyczne przesłanie europejskiego nakazu aresztowania do wszystkich uprawnionych podmiotów w państwach Schengen. System Informacyjny Schengen jest również wykorzystywany do działań antyterrorystycznych. SIS został zmodernizowany przez uruchomienie systemu nowej generacji SIS II (Widmański, 2007).

Mimo że Konwencja Wykonawcza oraz Kodeks Graniczny Schengen wskazują na wyjątkowy charakter okoliczności uzasadniających przywrócenie kontroli na granicach wewnętrznych, państwa członkowskie wielokrotnie korzystały z takiej możliwości. Jednak czyniły to ze stosownym wyprzedzeniem, informując Komisję i pozostałe państwa członkowskie. Powodem tych decyzji były w większości ważne spotkania przywódców państw (np. szczyty UE i NATO), wielkie imprezy sportowe (np. turnieje mistrzowskie w piłce nożnej: Mundial w Niemczech w 2006 r. lub EURO 2008 r. w Austrii i Szwajcarii oraz w 2012 r. w Polsce i na Ukrainie), zamachy terrorystyczne 
(Francja 2015) i kryzys imigracyjny 2015 i 2016 (Groenendijk, 2006, s. 67-68; Gruszczak, 2012, s. 39).

\section{Wpływ kryzysu imigracyjnego na funkcjonowanie strefy Schengen}

Szczególnym egzaminem dla strefy Schengen była sytuacja związana z wybuchem protestów antyreżimowych w krajach islamskich Afryki Północnej. Wydarzenia te spowodowały całkowitą destabilizację polityczną i społeczno-gospodarczą regionu, stanowiącą zagrożenie dla bezpieczeństwa wewnętrznego UE (zwłaszcza jej krajów południowych), wiązały się też z dramatem humanitarnym tysięcy osób uciekających z obszaru konfliktu i szukających schronienia na północnym wybrzeżu Morza Śródziemnego. W pierwszej połowie 2011 r. do Włoch napłynęło ok. 50 tys. imigrantów, co spowodowało przeludnienie na wyspie Lampedusa i skłoniło władze do ogłoszenia stanu kryzysu humanitarnego. Aby „,rozładować” presję imigracyjna, Włochy zdecydowały się przyznać ok. 20 tys. przybyszom tymczasowe prawo pobytu i dokumenty podróży. W reakcji na ten gest Francja jednostronnie przywróciła kontrolę na granicach z Włochami (Trojanowska-Strzęboszowa, 2012b, s. 18-19). W ślady władz francuskich poszła też Dania, która w maju wprowadziła stałe kontrole na granicach ze Szwecją i Niemcami. Państwa te domagały się takiej zmiany regulacji schengeńskich, aby dopuszczać możliwość jednostronnych decyzji państw członkowskich o czasowym przywróceniu kontroli na granicach wewnętrznych Unii Europejskiej. Należy podkreślić, że w istocie francuska propozycja reformy systemu Schengen oznaczała rozszerzenie uprawnień państw członkowskich w zakresie przywracania kontroli granicznych i znacznie osłabiała ponadnarodowy charakter całego systemu. Rozpoczęła się dyskusja nad zmianą zasad przywracania kontroli granicznej pomiędzy państwami członkowskimi a instytucjami ponadnarodowymi Komisją Europejską i Parlamentem Europejskim. Efektem tego było rozwiązanie kompromisowe. 12 VI 2013 r. ustanowiono nowe zasady zarządzania strefą Schengen, zawierające nowy mechanizm przywracania kontroli na granicach wewnętrznych. Zdecydowano, że jedyną przesłanką do przywrócenia kontroli pozostanie poważne i nagłe zagrożenie dla porządku publicznego lub bezpieczeństwa wewnętrznego na poziomie unijnym lub państwowym. Sprecyzowano równocześnie, że zagrożenie to odnosić się może do trzech sytuacji: dających się przewidzieć różnego typu wydarzeń np. sportowych czy politycznych; nagłych i nieprzewidzianych wydarzeń wymagających natychmiastowej reakcji, takich jak atak terrorystyczny czy poważny incydent przestępczy; utrzymującego się poważnego deficytu w zakresie kontroli granicy zewnętrznej - z zastrzeżeniem jednak, że jest to środek ostateczny. W odniesieniu do dwóch pierwszych sytuacji decyzje o przywróceniu kontroli granicznej pozostawiono w gestii państwa członkowskiego, które o tym zamiarze ma obowiązek poinformować inne państwa członkowskie i Komisje, wskazując także planowany zakres i okres trwania kontroli. Uznano, że w odniesieniu do planowanych wydarzeń kontrole będzie można przywrócić na okres do 30 dni z możliwością ich przedłużenia o kolejny trzydziestodniowy okres. Nie mogą one jednak trwać dłużej niż 6 miesięcy. Z kolei w sytuacjach nagłych i nieprzewidywalnych kontrole będzie można przywrócić na okres 10 dni i ewentualnie przedłużyć maksymalnie do 2 miesięcy. Wobec trzeciej możliwości przywracania kon- 
troli na granicach wewnętrznych wprowadzono specjalny, skoordynowany system decyzyjny, powiązany z nowo ustanowionym mechanizmem oceny funkcjonowania strefy Schengen. Orzeczenie o utrzymaniu się poważnego uszczerbku w kontroli określonego odcinka granicy zewnętrznej dokonywane będzie na podstawie specjalnego raportu przygotowanego jako część mechanizmu ewaluacyjnego i po wykazaniu, że zidentyfikowane niedociagnięcia utrzymują się pomimo zastosowania innych środków. W takich wyjątkowych okolicznościach Komisja może zaproponować Radzie rekomendowanie państwom członkowskim wprowadzenia kontroli na wspólnych granicach z państwem, które odpowiada za ochronę odcinka granicy zewnętrznej, na którym stwierdzono deficyty. Zdecydowano, że w takiej sytuacji kontrole będzie można przywrócić na okres 6 miesięcy, z możliwością ich trzykrotnego przedłużenia, co oznacza, że nie będą one mogły trwać dłużej niż 2 lata (Trojanowska-Strzęboszowa, 2014a, s. 67-68).

Z powodu kryzysu imigracyjnego zagrożony został układ z Schengen jeden $\mathrm{z}$ fundamentalnych filarów Unii Europejskiej; wolność poruszania się osób. Powojenna Europa przeżywa obecnie trzecią falę emigracji ${ }^{3}$, przede wszystkim z krajów afrykańskich i z Syrii.

W lipcu 2015 roku przypłynęła do państw Unii Europejskiej rekordowa liczba 107 tys. imigrantów; w czerwcu było ich 70 tys. Najwięcej imigrantów przypłynęło do Unii przez greckie wyspy, przybywając z Turcji (w lipcu 50 tys.); na drugim miejscu były Wegry (34 tys.), dalej Włochy (20 tys.). W pierwszej połowie 2015 roku Frontex (unijna agencja ds. granic) zanotował 340 tys. imigrantów, więcej niż w 2014 roku, kiedy przypłynęło ich 280 tys. (Rekordowy napływ emigrantów..., 2015). Najwięcej przybyszów pochodziło z Syrii około 82 tys., Afganistanu ok. 33 tys., Erytrei ok. 23,8 tys., Nigerii ok. 10,7 tys., Pakistanu ok. 6,4 tys. Z Afryki Subsaharyjskiej 9,8 tys. Mniejsze grupy przybywały z Wietnamu, Gruzji, Gwinei, Maroko, Gambii. Dodatkowo granice Unii Europejskiej przekroczyło 23,2 tys. Kosowian. Według Międzynarodowej Organizacji ds. Migracji od początku roku 2015 w Morzu Śródziemnym utonęło około 2,5 tys. osób. Według szacunków Biura Wysokiego Komisarza ds. Uchodźców prawie 200 tys. osób dostało się do Unii Europejskiej szlakiem z Turcji do Grecji, a 110 tys. z Libii do Włoch. Wykorzystywano, też trasy z Maroko do Hiszpanii, z Senegalu na Wyspy Kanaryjskie czy przez wschodnie granice Unii Europejskiej (Czarnecki, Jałoszewski, Kwaśniewski, 2015). Głównym celem imigrantów są Niemcy, które stały się atrakcyjne dla emigrujących do Europy, kiedy to odstapiły od zasad unijnych. Rząd w Berlinie ogłosił w sierpniu 2015 r., że będzie przyjmował syryjskie wnioski o azyl bez względu na państwo, do którego imigranci przybyli najpierw. Dotychczas o azyl mogli się oni ubiegać wyłącznie w pierwszym unijnym państwie, do którego przyjechali.

Fabrice Leggeri szef Frontexu poinformował, że do października 2015 roku, około 800 tys. nielegalnych imigrantów przekroczyło granice Unii Europejskiej. Stąd jego

${ }^{3}$ Pierwsza miała miejsce przed około 50 laty, kiedy to w okresie korzystnej koniunktury zaczęło brakować pracowników - zwłaszcza tych, którzy mogliby wykonywać prace, jakich nie podjęliby się obywatele krajów Zachodu. Przybyszów nie tylko ochoczo witano, lecz również - jak w przypadku zapraszanych do Belgii Marokańczyków - wręcz zachęcano do przyjazdu, osiedlenia się i podjęcia pracy. Emigranci z Azji i Afryki z reguły kierowali się do swoich byłych metropolii, gdyż na ogół dobrze znali język swoich kolonizatorów. Do krajów nieposiadających kolonii, jak RFN czy Szwajcaria, przybywali w poszukiwaniu pracy Turcy i Jugosłowianie. Druga fala emigracji nastapiła po przyjęciu do UE krajów Europy Wschodniej i otwieraniu dla ich obywateli rynków pracy. Zaczął się napływ nie tylko Polaków, lecz także niemile widzianych emigrantów z Rumunii. 
apel, aby państwa członkowskie UE zamiast rozlokowywać setki policjantów na granicach narodowych, zabezpieczyły zewnętrzną granicę UE, ponieważ prawdziwa granica przebiega przez Lampeduzę, Lesbos i Melillę (Już 800 tysięcy osób..., 2015).

\section{Mapa 1. Główne szlaki migracyjne do Europy, z poddanymi najliczniejszymi grupami migrantów}

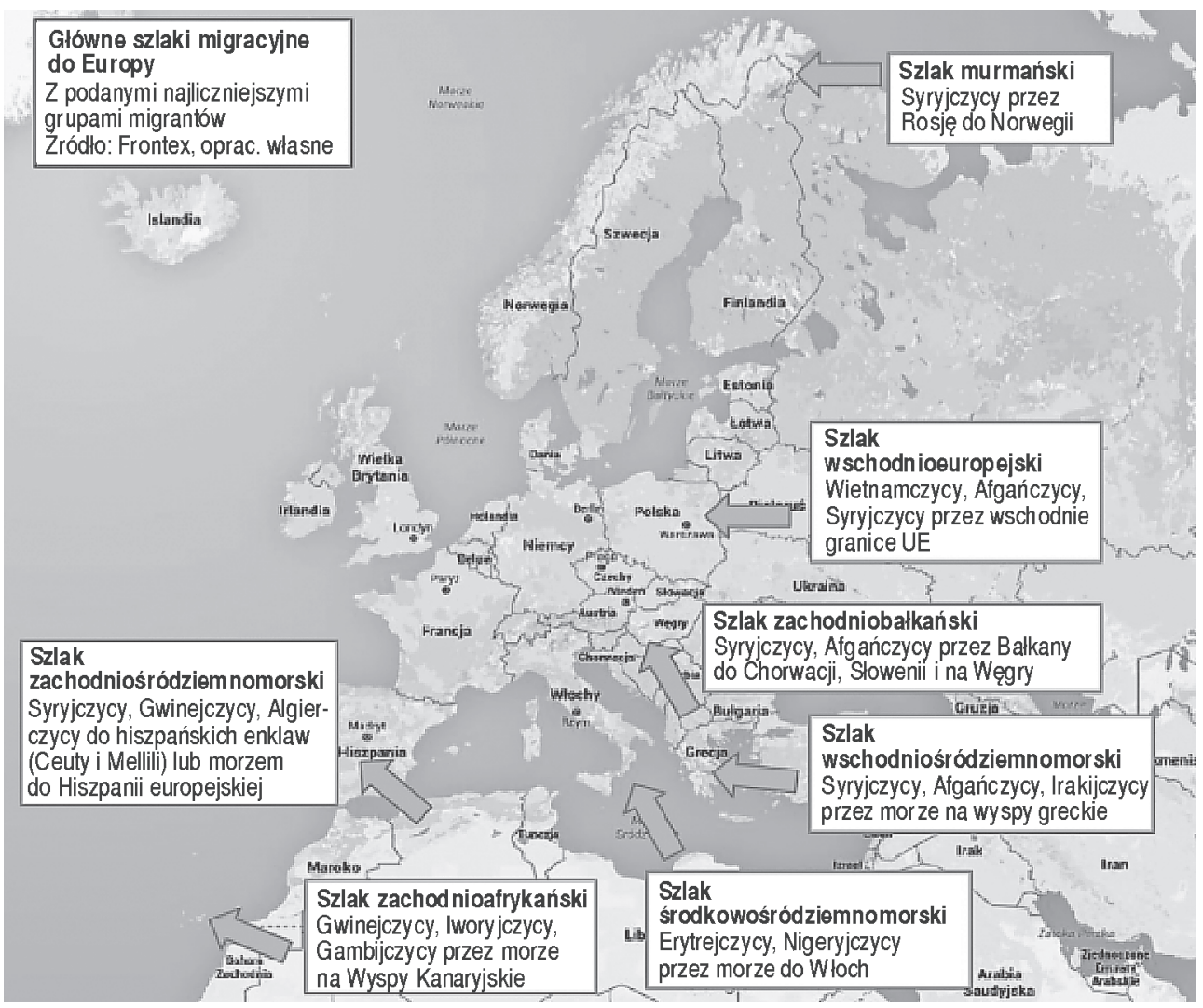

Źródło: Za http://biuletynmigracyjny.uw.edu.pl/53-grudzien-2015/glowne-szlaki-migracyjne-do-europy-zpodanymi-najliczniejszymi-grupami-migrantow.

Obecny ruch migracyjny tym różni się od poprzednich, że ludzie starają się dostać do Europy nie w poszukiwaniu pracy (choć i tacy się zdarzają), lecz po to by ratować życie. Istotnym problemem jest brak możliwości zapewnienia uchodźcom odpowiednich warunków życia i pracy. Tym bardziej, że na mocy prawa unijnego osoby ubiegające się o azyl mają mieć zagwarantowane prawo do pracy w okresie 9 miesięcy od przybycia. Obawy przed niekontrolowanym napływem uchodźców podsycane są z jednej strony, strachem przed wpuszczaniem islamskich ekstremistów wysyłanych przez tzw. Państwo Islamskie. $\mathrm{Z}$ drugiej z kolei widać narastanie tendencji nacjonalistycznych wśród politycznych elit europejskich. We Francji od lat silny jest Front Narodowy, również w Danii, w państwie znanym z otwartości wobec osób uciekających przed prześladowaniami, ponad 20\% w wyborach parlamentarnych 2015 roku, zdobyła Duńska Partia Ludowa, 
która podczas kampanii wyborczej opowiadała się przeciwko przyjmowaniu pozaeuropejskich uchodźców. Węgry w obawie przed emigrantami wybudowały mur o długości $175 \mathrm{~km}$ na granicy z Serbią. Premier Węgier Viktor Orbán tłumaczył tę decyzję faktem, że bogate państwa europejskie odsyłają z powrotem uchodźców, którzy przybyli tam przez Węgry, przekraczając granicę z Serbią. Zmuszone do przyjmowania uciekinierów z terenów zmagań wojennych państwa Unii Europejskiej stanęły przed dwoma problemami. Pierwszy - w jaki sposób zapewnić uchodźcom w miarę dobre warunki egzystencji. Drugi - jak powstrzymać kolejne fale przesiedleńców. Ten drugi problem starano się rozwiązać w sposób siłowy - poprzez walkę z przemytem uchodźców (Jaszczuk, 2015).

Zgodnie z najnowszymi badaniami, większość mieszkańców zachodniej Europy opowiada się za zakończeniem swobodnego przekraczania granic ze względu na narastający kryzys imigracyjny. Według sondażu IFOP, przeprowadzonego w wybranych państwach europejskich i opublikowanego w gazecie „Le Figaro”, 67\% Francuzów opowiedziało się za przywróceniem kontroli granicznych i likwidacją układu Schengen, który pozwala na podróżowanie bez paszportu w 26 europejskich państwach, w tym 22 państwach członkowskich UE. 63\% Brytyjczyków chce przywrócenia kontroli w innych krajach europejskich, podobnie jak większość Włochów (56\%) i Niemców (53\%) (Większość mieszkańców zachodniej Europy..., 2015). Na zakwestionowanie układu z Schengen przez społeczeństwa państw europejskich, złożyło się kilka kwestii między innymi: znaczne zwiększenie się liczby osób ubiegających się o azyl, wzrost znaczenia nacjonalistycznych partii, zamachy terrorystyczne, słabe ożywienie gospodarcze (Europe Rethinks the Schengen Agreement, 2015).

Państwa europejskie chwytały się różnych sposobów ograniczających napływ imigrantów. Jednym z nich była budowa murów na przykład na granicy Grecji z Turcja, Bułgarii z Turcją, Węgier z Serbią i Chorwacją. Zasieki i mury zaczęły także powstawać pomiędzy państwami strefy Schengen (np. pomiędzy Austrią i Słowenia), osłabiając tym samym jej struktury i potwierdzając obawy o jej przyszłość. Płoty zagrażają strefie Schengen nie bezpośrednio, ale jako wyraz braku europejskiej solidarności, który w czarnym scenariuszu może zniszczyć zdobycze integracji (Czarnecki, 2015).

Pojawiła się również propozycja utworzenia ministrefy Schengen, z inicjatywą której wystapiła Holandia, chciała ona w ten sposób kontrolować napływ imigrantów i osób ubiegających się o azyl. Pomysł holenderskich dyplomatów zakładał utworzenie małej strefy Schengen w miejsce obecnej, jednoczącej większość państw UE. Nowe rozwiązanie umożliwiałoby przekraczanie granic bez kontroli paszportowych tylko w państwach Beneluksu (Belgia, Holandia, Luksemburg) oraz w Niemczech i Austrii. By wjechać na ten obszar należałoby przejść normalną procedurę graniczną. Jednak spora część państw m.in. Niemcy, Austria, Luksemburg, Polska, skrytykowała ten pomysł, który w konsekwencji mógłby zagrozić funkcjonowaniu strefy Schengen, a nawet stać się początkiem końca Unii Europejskiej. Powstanie małej strefy Schengen oznaczałoby powstanie Europy dwóch prędkości, a na państwa pozostające poza spadłby ciężar radzenia sobie z falą imigrantów. Wprowadzenie takiego rozwiązania jest prawnie możliwe. Aby zmienić traktat z Schengen jest wymagana zgoda większości jego sygnatariuszy (Upadek Europy bez granic..., 2015).

Odpowiedzią ze strony Unii Europejskiej na rosnąca falę imigracji była strategia migracyjna przedstawiona w kwietniu 2015 roku na szczycie UE w Brukseli. Szefowie 
państw i rządów, postanowili pomóc „,państwom frontowym” i na zasadach dobrowolności włączyć się w program relokacji uchodźców. Założono, że system relokacji będzie działać tymczasowo i odciążyć ma państwa na południu Europy, do których przez Morze Śródziemne docierają tysiące imigrantów z Afryki i Bliskiego Wschodu. Uchodźcy mieliby być rozmieszczani w poszczególnych państwach UE według klucza opartego przede wszystkim na wielkości PKB oraz liczbie ludności, a także poziomie bezrobocia oraz liczbie już przyjętych uchodźców w latach 2010-2014. Zapowiedziano również, że zaproponowany zostanie trwały system rozmieszczania uchodźców w Unii w sytuacjach zwiększonego ich napływu. Jednak nie wzbudziło to entuzjazmu we wszystkich państwach UE, bowiem obowiązkowe kwoty rozmieszczania przybyszów od początku miały swoich zwolenników, jak Niemcy czy Włosi i przeciwników Węgry, Wielka Brytania i Czechy (Komisja Europejska zamierza ..., 2015).

W związku z narastającym kryzysem migracyjnym i walką z nielegalną migracją przygotowano europejski program w zakresie migracji, opublikowany w dniu 13 maja $2015 \mathrm{r}$. W programie tym określono cztery poziomy działań służących realizacji uczciwej, solidnej i realistycznej polityki migracyjnej UE.

1. Ograniczenie zachęt dla nielegalnych migrantów poprzez zajęcie się pierwotnymi przyczynami nielegalnej i wymuszonej migracji, walkę z przemytnikami i handlarzami ludźmi, opracowanie „Podręcznika powrotów”, wzmocnienie mandatu Frontexu w celu zwiększenia zdolności do świadczenia kompleksowej pomocy operacyjnej i monitorowanie wdrażania dyrektywy w sprawie powrotów; uczynienie migracji kwestią kluczową dla delegatur UE.

2. Zarządzanie granicami - ratowanie życia i zabezpieczanie granic zewnętrznych poprzez wzmocnienie roli i zdolności Frontexu, ustanowienie normy unijnej w zakresie zarządzania granicami, wzmocnienie koordynacji UE w odniesieniu do zadań straży przybrzeżnej, zmienienie wniosku w sprawie inteligentnych granic, wzmocnienie zdolności państw trzecich do zarządzania własnymi granicami.

3. Obowiązek Europy w zakresie ochrony - zdecydowana wspólna polityka azylowa poprzez ustanowienie nowego systemu monitorowania i oceny wspólnego europejskiego systemu azylowego oraz wytycznych w celu poprawienia norm dotyczących warunków przyjmowania i procedur azylowych, stworzenie wytycznych w zakresie walki z nadużywaniem systemu azylowego, wzmocnienie przepisów dotyczących bezpiecznego państwa pochodzenia zawartych $\mathrm{w}$ dyrektywie $\mathrm{w}$ sprawie procedur azylowych, aby wspierać sprawne rozpatrywanie wniosków osób ubiegających się o azyl z państw uznanych za bezpieczne, zorganizowanie środków promujących systematyczną identyfikację oraz pobieranie odcisków palców, wprowadzenie identyfikatorów biometrycznych w Eurodac, dokonanie ocen i ewentualny przegląd rozporządzenia dublińskiego w $2016 \mathrm{r}$.

4. Wprowadzenie nowej polityki dotyczącej legalnej migracji poprzez modernizację i przekształcenie systemu niebieskiej karty, zorganizowanie platformy dialogu z partnerami społecznymi w sprawie migracji ekonomicznej, bardziej zdecydowane działania w celu powiązania polityki w zakresie migracji i rozwoju, zmianę priorytetów finansowania polityki integracyjnej, zorganizowanie tańszych, szybszych i bezpieczniejszych przekazów pieniężnych (Komunikat Komisji do Parlamentu Europejskiego..., 2015). 
We wrześniu 2015 r. Komisja Europejska w komunikacie prasowym przedstawiła obszerny pakiet działania obejmujący: wniosek w sprawie nadzwyczajnej relokacji z Grecji, Węgier i Włoch 120 tys. osób; stały kryzysowy mechanizm relokacji dla wszystkich państw członkowskich; wspólną europejską listę bezpiecznych krajów pochodzenia; wspólną procedurę powrotów i plan działania UE w zakresie powrotów, zapewniające wyższą skuteczność powrotów migrantów; komunikat w sprawie zasad zamówień publicznych na środki wspierające uchodźców; komunikat w sprawie podejścia do zewnętrznego wymiaru problemu uchodźców; nadzwyczajny fundusz powierniczy na rzecz Afryki. W sumie relokacji miało być poddane 160 tys. imigrantów. Była to suma transferu 40 tys. osób zaakceptowanych przez Parlament Europejski w dniu 9 września 2015 roku i przyjęta przez Radę ds. Wymiaru Sprawiedliwości i Spraw Wewnętrznych w dniu 4 września 2015 roku oraz 120 tys. osób zgodnie z decyzją Rady UE (Adamczyk, 2016, s. 51-53).

Wraz ze zwiększającym się napływem uchodźców jesienią 2015 roku Niemcy, Austria, Dania, Szwecja i Norwegia wprowadziły tymczasowe kontrole na części swoich granic. Obowiązywały one na granicach austriacko-węgierskiej i austriacko-słoweńskiej, niemiecko-austriackiej, w duńskich portach z połączeniami promowymi do Niemiec i na lądowej granicy między Niemcami a Danią, w szwedzkich portach w południowo-zachodnim regionie kraju oraz na moście nad cieśniną Sund, a także w norweskich portach z połączeniami do Danii, Niemiec i Szwecji. Po ataku terrorystycznym do jakiego doszło 13 listopada 2015 r. we Francji również wprowadzono kontrolę na granicach i utrzymało ją do 26 lutego 2016 roku (Komunikat Komisji do Parlamentu Europejskiego i Rady..., 2015). Pomimo, iż Komisja Europejska przyznała, iż w 2016 roku napływ uciekinierów z Bliskiego Wschodu i Afryki do Europy zmniejszył się, ale stwierdziła jednocześnie, że „nadal istnieją nadzwyczajne okoliczności” uprawniające do przedłużenia kontroli na niektórych granicach wewnętrznych Schengen. 12 maja 2016 roku Rada na wniosek Komisji Europejskiej podjęła decyzję wykonawczą w sprawie utrzymania kontroli przez kolejne sześć miesięcy, czyli do 12 listopada 2016 roku. Z kolei 25 października 2016 roku Rada na wniosek pięciu państw należących do strefy Schengen; Austrii, Niemiec, Danii, Szwecji i Norwegii zaleciła tym państwom przedłużenie proporcjonalnych tymczasowych kontroli granicznych o maksymalnie trzy miesiące od dnia przyjęcia niniejszej decyzji wykonawczej na następujących granicach wewnętrznych: - w przypadku Austrii - na granicy lądowej austriacko-węgierskiej i granicy lądowej austriacko-słoweńskiej; - w przypadku Niemiec - na granicy lądowej niemiecko-austriackiej; - w przypadku Danii - w duńskich portach z połączeniem promowym z Niemcami i na granicy lądowej duńsko-niemieckiej; - w przypadku Szwecji - w szwedzkich portach w regionie policyjnym południowym i zachodnim oraz na moście nad Sundem; - w przypadku Norwegii - w norweskich portach z połączeniem promowym z Danią, Niemcami i Szwecją (Decyzja Wykonawcza Rady przedstawiajaca..., 2016).

Działając w kierunku zagwarantowania bezpieczeństwa, które zdaniem wielu zostało naruszone w wyniku kryzysu migracyjnego, UE postanowiła lepiej wykorzystywać bazy danych i zdobywać informacje o terrorystach, innych przestępcach, wszystkich podejrzanych oraz zaginionych. Brane jest pod uwagę powołanie specjalnych unijnych służb patrolujących granice. Rozważane jest także wprowadzenie przepisów o kontroli paszportowej wszystkich osób przekraczających granice strefy Schengen. Do tej pory takiej kontroli podlegali tylko obcokrajowcy będący obywatelami państw spoza UE (Życie 
po Schengen ..., 2015). Rozpatruje się również wprowadzenie systematycznych kontroli także osób z paszportami Unii, np. przybywających z jakiegoś kierunku czy państwa, jeżeli uznane zostanie, że istnieje jakieś zagrożenie (Widzyk, 2015).

Nasilający się kryzys imigracyjny, spowodował, że Niemcy zaczęły borykać się z dużym napływem przybyszów, wówczas kanclerz Niemiec Angela Merkel ostrzegła, że trwałe utrzymanie systemu swobodnego przemieszczania się w Europie w ramach obszaru Schengen zależy od wprowadzenia mechanizmu solidarnego rozdziału imigrantów pomiędzy państwa Unii Europejskiej. Szefowa niemieckiego rządu zwróciła uwagę na fakt, że kiedy tworzono strefę Schengen, nie uzgodniono co robić w sytuacjach nadzwyczajnych, gdy europejską granicę zacznie przekraczać ogromna liczba imigrantów. Dlatego, jej zdaniem, trzeba podjacc kolejne kroki i utworzyć stały mechanizm podziału uchodźców między państwa członkowskie (Merkel: Przyszłość strefy Schengen, 2015).

$\mathrm{W}$ ramach walki z narastającym kryzysem imigracyjnym w dniach 11 i 12 listopada 2015 r. europejscy i afrykańscy przywódcy spotkali się w Valletcie na szczycie poświęconym migracji, aby zacieśnić współpracę oraz zająć się bieżącymi wyzwaniami i możliwościami związanymi z migracją. Punktem wyjścia było uznanie, że migracja to wspólny problem państw pochodzenia, państw tranzytu i państw docelowych. Przywódcy uczestniczący w szczycie przyjęli deklarację polityczną i plan działania, których celem była eliminacja pierwotnych przyczyn nieuregulowanej migracji i czynników zmuszających ludzi do opuszczania miejsc zamieszkania, zacieśnienie współpracy w zakresie legalnej migracji i mobilności, zwiększenie ochrony migrantów i osób ubiegających się o azyl, zapobieganie nieuregulowanej migracji, przemytowi migrantów i handlowi ludźmi oraz walka z tymi zjawiskami, zacieśnienie współpracy w zakresie powrotów, readmisji i reintegracji.

Z kolei na szczycie UE-Turcja 29 listopada 2015 r. Unia Europejska i Turcja przyjęły wspólny plan działań, którego celem było zahamowanie fali migracji do Europy. UE zapowiedziała m.in. przekazanie 3 mld euro wsparcia na pomoc dla ponad 2 milionów uchodźców z Syrii, którzy schronili się w Turcji. Przełamany został też impas w procesie negocjacji w sprawie przystąpienia Turcji do UE. Zapowiedziano otwarcie nowego rozdziału negocjacyjnego, dotyczącego polityki gospodarczej i monetarnej. Unia Europejska zawarła porozumienie z Turcją o współpracy w walce z kryzysem migracyjnym. Decyzję ogłoszono na zakończenie szczytu w belgijskiej stolicy. Wśród przywódców państw europejskich zrodziła się nadzieja, iż władze w Ankarze zatrzymają falę uchodźców, którzy próbują dostać się do Europy (Wspólny plan dziatania Unii i Turcji, 2015).

Konsekwencją podjętych przez państwa europejskie działań jest spadek napływu imigrantów do Europy. Według wstępnych danych w 2016 roku do Europy przedostało się dwoma głównymi szlakami morskimi 364 tysiące imigrantów. Na greckie wyspy przez Morze Egejskie dotarło 182 tys. osób, o 79\% mniej niż w 2015 roku. Jak podaje Frontex, ten spadek jest przede wszystkim konsekwencją zawarcia w marcu 2015 roku porozumienia między UE a Turcją, które doprowadziło do zaostrzenia przez tureckie władze kontroli granic i walki z przemytnikami ludzi oraz umożliwiło odsyłanie do Turcji wszystkich nielegalnych imigrantów przedostających się na greckie wyspy. Także uszczelnienie granic przez państwa położone na tzw. bałkańskim szlaku migracyjnym przyczyniło się do spadku liczby imigrantów (Frontex: mniej uchodźców dociera do Europy..., 2016). 
Reasumując: Układ z Schengen to porozumienie między państwami, dotyczące zniesienia kontroli na granicach, wprowadzania zasad swobodnego przepływu obywateli oraz wzmocnienia współpracy w zakresie bezpieczeństwa i polityki azylowej. Strefa Schengen jest najbardziej widocznym przykładem europejskiej jedności, sprzyjającym zacieśnianiu więzi gospodarczych między 26 członkami tego obszaru, jak i terenem wzmacniającym turystykę. Jednak mimo swej symbolicznej i gospodarczej wagi jej istnienie zostało zagrożone z powodu utrzymującego się napływu imigrantów z Bliskiego Wschodu i Afryki Północnej. Problemy w strefie Schengen wynikają z faktu, że jest ona niekompletna jako system. Brakuje jej wspólnie wypracowanego, skutecznego mechanizmu regulującego ochronę granic zewnętrznych. Zaproponowane przez Komisję Europejską rozwiązania wzmocnienia unijnej agencji ochrony granic Schengen i zmiana unijnych procedur azylowych zostały ocenione pozytywnie przez państwa wchodzące w skład strefy Schengen. Ciekawym pomysłem na zażegnanie kryzysu jest ograniczenie napływu imigrantów poprzez stworzenie funduszu wspierania migrantów tam gdzie oni się znajdują, często w ośrodkach dla uchodźców jeszcze poza granicami europejskimi. Międzynarodowe wsparcie dla państw najbardziej obciążonych pomocą uchodźcom ma też sens z ekonomicznego punktu widzenia: koszt rocznego utrzymania jednego uchodźcy w Jordanii wynosi około 3 tys. euro; w Niemczech - co najmniej 12 tys. euro (Uchodźcy. Jak wyjść z kryzysu). Stąd istotna jest pomoc dla Turcji by umożliwiła odbudowę Kurdystanu syryjskiego i powrót do niego uchodźców (Lindenberg, 2015). Jednak szereg propozycji Komisji Europejskiej w sprawie uchodźców napotyka opór niektórych rządów, co może doprowadzić, do utworzenia przez państwa stanowiące trzon UE własnej strefy Schengen, okrojonej o tych członków, którzy nie chcą stosować się do wspólnej polityki azylowej. Jeśli państwa europejskie i UE chcą zapanować nad kryzysem migracyjnym i nie dopuścić do rozpadu strefy Schengen, muszą działać na wielu frontach jednocześnie - dążyć do rozejmu w Syrii, skierować znacznie większe środki na wsparcie Turcji, Jordanii i Libanu, które przyjęły najwięcej imigrantów i zwiększyć swe możliwości w zakresie udzielania imigrantom schronienia i pomagania im w zintegrowaniu się ze społeczeństwem (Ostatnia szansa na uratowanie strefy Schengen..., 2016). Pomimo krytyki i kwestionowania istnienia strefy Schengen najprawdopodobniej w najbliższym czasie ona się nie rozpadnie. Państwa wchodzące w skład obszaru Schengen doceniają korzyści wynikające z jego funkcjonowania: redukcja czasu i kosztów transportu towarów w całej Europie, korzyści dla turystów i ludzi mieszkających w miastach granicznych, zaoszczędzenie pieniędzy w kwestii patrolowania granic lądowych. Wszystko jednak wskazuje na to, że układ z Schengen zostanie zreformowany i dostosowany do nowych okoliczności z dużym naciskiem na wzmocnienie kontroli granic zewnętrznych.

\section{Bibliografia}

Adamczyk A. (2016), Kryzys imigracyjny w UE i sposoby jego rozwiazania, „Przegląd Politologiczny”, $\mathrm{nr} 3$.

Bezpieczeństwo czy wolność? Schgengen musi się zaadoptować do tragicznych okoliczności, 20.11.2015, http://tvn24bis.pl/ze-swiata,75/schengen-musi-sie-zaadaptowac-do-tragicznychokolicznosci,596139.html, 2.12.2015. 
Czapliński W. (1992), Uktady z Schengen, „Przegląd Zachodni”, nr 1.

Czarnecki M. (2015), Płoty zagrażaja Schengen, http://wyborcza.p1/1,75477,19104490,ploty-zagrazaja-schengen.html, 1.12.2015.

Czarnecki M., Jałoszewski M., Kwaśniewski T. (2015), Uchodźcy w Polsce, „Gazeta Wyborcza”, nr 188, z dnia 18-20.09.2015.

Decyzja Wykonawcza Rady przedstawiajaca zalecenie w sprawie przedtużenia tymczasowych kontroli na granicach wewnętrznych w wyjatkowych sytuacjach stwarzajacych ryzyko dla ogólnego funkcjonowania strefy Schengen (2016), https://ec.europa.eu/transparency/regdoc/rep/1/2016/ PL/COM-2016-711-F1-PL-MAIN.PDF, 11.10.2016.

Dereń K. (2014), Rozwój strefy Schengen, http://www.psz.p1/120-unia-europejska/rozwoj-strefy-schengen, 18.09.2015.

Europe Rethinks the Schengen Agreement (2015), https://www.stratfor.com/analysis/europe-rethinksschengen-agreement.

„Financial Times”: kryzys imigracyjny zagraża strefie Schengen, 21.08.2015, http://wiadomosci. wp.pl/kat,1356,title,Financial-Times-kryzys-imigracyjny-zagraza-strefie-Schengen,wid, 17790816, wiadomosc.html?ticaid=115774\&_ticrsn=3, 7.12.2015.

Frontex: mniej uchodźców dociera do Europy przez morze, http://www.tvn24.pl/wiadomosci-ze-swiata,2/frontex-w-2016-r-o-2-3-mniej-imigrantow-dotarlo-do-ue-przez-morze, 705029.html.

Groenendijk K. (2006), Przywracanie kontroli na wewnętrznych granicach Europy - po co i przeciw komu, „Nowa Europa. Przegląd Natoliński”, nr 2.

Gruszczak A. (2012), Schengen - kłopotliwy sukces, „Nowa Europa. Przegląd Natoliński”, nr 2.

Jaszczuk B. K. (2015), Europa nie radzi sobie z problemem uchodźców, http://strajk.eu/europa-nie-radzi-sobie-z-problemem-uchodzcow/, 23.08.2015.

Jest decyzja w sprawie kwot uchodźców. Tylko cztery państwa przeciw (2015), http://www.tvp. info/21736781/jest-decyzja-w-sprawie-kwot-uchodzcow-tylko-cztery-panstwa-przeciwko, 4.12.2015.

Już 800 tys. osób nielegalnie przekroczyło granice Unii Europejskiej (2015), http://wiadomosci.dziennik.pl/swiat/artykuly/504723,kryzys-imigracyjny-800-tys-osob-nielegalnie-przekroczylo-granice-ue.html, 23.11.2015.

Kodeks Graniczny Schengen (2006), http://eur-lex.europa.eu/legal-content/PL/TXT/?uri=celex: 32006R0562, 11.05.2015.

Komisja Europejska zamierza wysłać do Polski część uchodźców z Afryki (2015), http://www.polskieradio.pl/5/3/Artykul/1441641,Komisja-Europejska-zamierza-wyslac-do-Polski-czescuchodzcow-z-Afryki, 4.11.2015.

Komunikat Komisji do Parlamentu Europejskiego i Rady. Ósme sprawozdanie pótroczne z funkcjonowania strefy Schengen 1 maja-10 grudnia 2015 r. (2015), https://ec.europa.eu/transparency/ regdoc/rep/1/2015/PL/1-2015-675-PL-F2-1.PDF, 11.10.2016.

Komunikat Komisji do Parlamentu Europejskiego, Rady, Europejskiego Komitetu EkonomicznoSpołecznego i Komitetu Regionów, Europejski Program w Zakresie Migracji, Bruksela, dnia 13.5.2015 r. (2015), https://ec.europa.eu/home-affairs/sites/homeaffairs/files/what-we-do/policies/european-agenda-migration/background-information/docs/communication_on_the_european_agenda_on_migration_pl.pdf, 19.10.2016.

Konwencja Wykonawcza do Układu z Schengen z dnia 19. 06. 1990 r. z dołaczonym aktem Końcowym i wspólnymi deklaracjami, Dz. Urz. WE L 239 z 22.09.2000 r., s. 10.

Lesiewicz E. (2015), Zróżnicowanie procesów integracji europejskiej. Wybrane problemy, Poznań.

Lindenberg G. (2015), 12 faktów pomocnych w dyskusji o uchodźcach, 14.09.2015, http://wyborcza.pl/ 1,75968,18811479,12-faktow-pomocnych-w-dyskusji-o-uchodzcach.html\#ixzz3tFyvYVWk, 6.12.2015. 
Merkel: Przyszłość strefy Schengen uzależniona od podziału uchodźców (2015), http://wiadomosci. dziennik.pl/swiat/artykuly/506533, angela-merkel-wazy-sie-przyszlosc-strefy-schengen.html, 3.12.2015.

Obecny kryzys migracyjny (2015), http:/uchodzcy.info/infos/obecny-kryzys-migracyjny/, 28.10.2016.

Ostatnia szansa na uratowanie strefy Schengen. „Financial Times” ostrzega Europe (2015), http:// wiadomosci.wp.pl/kat,1356, title, Ostatnia-szansa-na-uratowanie-strefy-Schengen-FinancialTimes-ostrzega-Europe,wid,18116500, wiadomosc.html.

Pyl G. (2008), Rozszerzenie strefy Schengen - swobodny przeptyw i jego konsekwencje w życiu codziennym, w: Polska w strefie Schengen. Refleksje po pierwszym roku członkostwa, Warszawa.

Rekordowy napływ emigrantów do Unii (2015), http://www.euroislam.pl/index.php/2015/08/rekordowy-naplyw-imigrantow-do-unii/, 21.08.2015.

Traktat o Unii Europejskiej, wersja skonsolidowana (2000), wprowadzenie i przekład J. Barcz, Warszawa.

Trojanowska-Strzęboszowa M. (2014a), Przywracanie kontroli na granicach wewnętrznych strefy Schengen, w: System Schengen a imigracja z perspektywy Polski i Niemiec, Warszawa.

Trojanowska-Strzęboszowa M. (2012b), Uwarunkowania ponadnarodowe i międzynarodowe polskiej prezydencji w Radzie UE, „Studia Europejskie”, nr 4.

Uchodźcy. Jak wyjść z kryzysu, http://projectsyndicate.natemat.pl/153531,uchodzcy-jak-wyjsc-zkryzysu, 6.12.2015.

Upadek Europy bez granic coraz bliższy. Mała strefa Schengen ucieszy Niemców (2015), http:// www.pch24.pl/upadek-europy-bez-granic-coraz-blizszy--mala-strefa-schengen-ucieszyniemcow,39598,i.html, 5.12.2015.

Wersja skonsolidowana Traktatu o funkcjonowaniu Unii Europejskiej, http://oide.sejm.gov.pl/oide/index.php?option=com_content\&view=article\&id=14804\&Itemid=946, 10.09.2015.

Wersja skonsolidowana Traktatu ustanawiajqcego Wspólnotę Europejska, http://oide.sejm.gov.pl/oide/ index.php?option=com_content\&view=article\&id=14436\&Itemid=436, 10.09.2015.

Widmański L. (2007), System Informacyjny Schengen - podstawowy instrument funkcjonowania strefy Schengen, Edukacja Prawnicza.

Widzyk A. (2015), Holandia ma pomyst na ,,ministrefę Schengen”, http://www.bankier.pl/wiadomosc/ Holandia-ma-pomysl-na-ministrefe-Schengen-3443713.html, 1.12.2015.

Większość mieszkańców zachodniej Europy chce zniesienia Schengen (2015), http://ndie.pl/wiekszoscmieszkancow-zachodniej-europy-chce-zniesienia-schengen/, 21.08.2015.

Wspólny plan działania Unii i Turcji, 29.11.2015, http://www.tvn24.pl/wiadomosci-ze-swiata,2/imigranci-w-ue-szczyt-ue-turcja,598576.html, 3.12.2015.

Życie po Schengen. Nie poradzimy sobie bez przywrócenia granic (2015), https://wszystkoconajwazniejsze.pl/bill-emmott-zycie-po-schengen/, 2.12.2015.

\section{Schengen area in times of immigration crisis}

\section{Summery}

The subject of the consideration in this article are issues related to the functioning of the Schengen area in times of the 2015/2016 immigration crisis in Europe. The Author of this article firstly referred to the origins of the crisis, the role of the Schengen area in the process of integrating the European continent, and then analyzed the phenomenon of uncontrolled growth of immigrants coming to Europe, taking into account decisions, initiatives and activities of certain Schengen area countries and the impact of these actions on running of the Schengen zone. In conclusion, the author stated 
that in times of serious difficulties, the Schengen area would probably survive, but it has to undertake certain steps (reforms, strengthening of the external border controls) helping to adapt to the new circumstances.

Key words: Schengen area, immigration crisis, immigrants, Europe, the European Union 